\title{
Obstacles to a Conceptual Framework for Sustainable Forest Management Under REDD in Central Africa: A Two-Country Analysis
}

\author{
Richard S. Mbatu \\ Environmental Sustainability \\ College of Science, Health and the Liberal Arts \\ Philadelphia University, Philadelphia \\ U.S.A
}

\section{Introduction}

Climate change is now an issue of concern at both national and international levels. In the past three decades efforts to address causes of climate change have focused mostly on mitigation measures of carbon emissions from conventional fossil fuels combustion - coal, oil, and natural gas. However, since 2000 after the $6^{\text {th }}$ Conference of the Parties (COP) of the United Nations Intergovernmental Panel on Climate Change (IPCC) at The Hague, forests have gained increased recognition in their role in the fight against climate change. Forests are now almost at par with conventional fossil fuels at the top of the international climate change agenda.

With close to 60 gigatons of carbon (Gt C) exchanged between terrestrial ecosystems and the atmosphere every year; with the world's tropical forests estimated to contain $428 \mathrm{Gt} C$ in vegetation and soils; with the loss of tropical forests as the major driver of the $\mathrm{CO}_{2}$ flux caused by land-use changes during the past two decades (Lasco, 2010); with deforestation accounting for about 17 percent of all $\mathrm{CO}_{2}$ emissions (Intergovernmental Panel on Climate Change [IPCC], 2007); and with little results achieved so far on mitigation measures of carbon emissions from fossil fuels combustion, the 13 th COP meeting in 2007 in Bali, Indonesia, adopted a more rigorous emissions reduction mechanism on 'avoided deforestation' scheme, codenamed REDD. REDD (or REDD +$)^{1}$ is an acronym which stands for Reducing Emissions from Deforestation and Degradation. REDD provides a framework for mitigating greenhouse gas emissions from deforestation and forest degradation through market instruments and financial incentives.

Given that the majority of the world's tropical forests are located in developing countries which are generally poor, "REDD presents a tremendous opportunity to jointly address climate change and rural poverty, while sustaining ecosystem services and conserving

\footnotetext{
${ }_{1}^{1}$ Since 2008 after COP-14 in Poznań, the symbol ' + ' has been added to the REDD acronym in some publications in recognition of the fact that "climate benefits can arise not only from avoiding negative changes (deforestation, degradation), but also from enhancing positive changes, in the form of forest conservation and restoration" (Angelsen \& Wertz-Kanounnikoff, 2008, as cited in Wertz-Kanounnikoff \& Kongphan-apirak, 2009).
} 
biodiversity" (Huberman, 2007). In this regard, sustainable forest management (SFM) in developing countries must be emphasized as an essential element for the attainment of the goals of REDD. Of the three major tropical forests regions in the world - Amazonia, Congo Basin and South-east Asia - the Congo Basin in Central Africa is the most impoverished. The implementation of REDD scheme in this region through SFM could create incentives for poverty alleviation while at the same time limiting deforestation and forest degradation thus making meaningful contribution to the fight against climate change. Although some countries in this region, since the conception of the scheme in 2007, have made significant progress in the preparedness process for a post-2012 REDD mechanism, it should be noted that mostly pilot projects have been carried out so far, with most of them marred by many difficult and controversial issues that need to be addressed before actual implementation can begin. Among the issues to be addressed are: 1) the problem of leakage. That is, the ability to control emissions beyond project and country boundaries, 2) the problem of determining the base-line. That is, how much deforestation has been avoided and how much deforestation is too much deforestation, 3) the problem of potential non-permanence. That is, how to deal with emissions resulting from natural and human causes at a later date, 4) the problem of price. That is, how the demand for carbon credits influences supply by REDD, and 5) the problem of tenure and usage rights (ownership of the land, and illegal logging control), weak economic, political and legal structures, and poor industrial practices in the forestry and agricultural sectors.

Efforts to address these problems have been largely focused on technical issues (problems 14), while not much attention has been given to the socio-economic and development needs (problem 5) of forest-dependent communities. With millions of people in the Congo Basin depending on the forest for their livelihoods, the importance of fully integrating the socioeconomic and development needs of forest communities into REDD's agenda in this region cannot be undermined. As David Huberman of International Union for the Conservation of Nature (IUCN) observes "the success of REDD will ultimately depend on how well it contributes to the development needs of forest-dependent communities" (Huberman, 2007). In this regard, this chapter is aim at explaining the challenges of REDD beyond the technical problem area. It focuses on the socio-economic, political and legal challenges of implementing the REDD scheme in two countries in the Congo Basin in Central Africa Cameroon and Democratic Republic of Congo (DRC). The chapter critically reviews different factors leading to deforestation in these countries and explore potential pathways towards SFM under REDD. We argue that an architecture based on socio-economic structure that is incentive driven (financial incentive), is more likely to achieve the goals of REDD in the Congo Basin than a technical-base architecture driven by market instruments.

The methodological approach to this chapter is narrative, descriptive, and analytic review of documents and empirical data from various sources inspired by debates and events related to REDD in the Congo Basin in general and in Cameroon and DRC in particular.

\section{The origins of REDD and the ongoing process}

Multilateral agreements and conventions under the auspices of the United Nations are largely responsible for the resolution of many environmental problems that are of the global magnitude. This includes the convention on the Law of the sea protecting the open seas from various forms of abuses, the convention on trade on endangered species, the Montreal Protocol dealing with the elimination of substances that deplete the ozone layer, 
etc. The Montreal Protocol is described by many as the most successful international environmental agreement this far. It is a fairly accurate description, especially when compared with the challenge of the global climate change problem in the wake of the failing Kyoto Protocol. The Kyoto Protocol was crafted in Kyoto, Japan in December of 1997 by the international community under the auspices of the Intergovernmental Panel on Climate Change (IPCC) in an effort to cut back on global greenhouse gas (GHG) emissions, known to be the major cause of global warming and resulting climate change. The IPCC was formed by the United Nations Environment Program (UNEP) and the World Meteorological Organization (WMO) in 1988 after the global community began noticing signs of climate change in the early 1980s. After its first and second conferences in the early 1990s, the IPCC presented a draft treaty during the second World Summit on the environment in Rio de Janeiro, Brazil in 1992, called the United Nations Framework Convention on Climate Change (UNFCCC). The UNFCCC became a binding agreement three years later in 1995 after 128 nations ratified the agreement. Every year since its ratification in 1995 the UNFCCC holds a conference of Parties of the convention (COP). It was during the $3^{\text {rd }}$ COP in 1997 that the Kyoto Protocol was reached. A crucial element of the UNFCCC under the Kyoto Protocol is the undertaking by some developed countries to reduce emission of six greenhouse gases (carbon dioxide, methane, sulfur hexafluoride, nitrous oxide, hydrofluorocarbons and perfluorinated hydrocarbons) to at least $5 \%$ below 1990 levels, to be achieved by 2012. This was in recognition that the developed countries have a greater responsibility to emissions reductions than other Parties of the convention. Accordingly, all Parties of the convention are "classified [on the bases of] their levels of development and their commitments for GHG emission reduction and reporting [as follows]" (Randolph \& Masters, 2008):

1. Annex I Parties: European Union (EU) member states plus other developed countries that aim to reduce emissions to pre-1990 levels.

2. Annex II Parties: The most developed countries in Annex I, which also commit to help support efforts of developing countries.

3. Countries with economies in transition (EIT): An Annex I subset mostly eastern and central Europe, and the former Soviet Union, which do not have Annex II obligations.

4. Non-Annex I Parties: All others, mostly developing countries, which have fewer obligations and should rely on external support to manage emissions.

In efforts to facilitate emissions reduction COP at its $6^{\text {th }}$ meeting at The Hague in 2000, developed three flexible mechanisms to give more options to Parties of the convention in meeting their required reduction targets. These include: (1) the Clean Development Mechanism $(\mathrm{CDM})^{2}$, (2) the Joint Implementation (JI) ${ }^{3}$, and (3) Emissions Trading (ET) ${ }^{4}$. However, in spite allowing greater flexibility in meeting emissions reduction targets, these three mechanisms considered forests only for their carbon sequestration function, leaving out their potential of reducing emissions from deforestation and degradation. The question

\footnotetext{
2 The CDM mechanism allows industrialized countries to invest in clean energy projects in developing countries that are related to carbon emissions reduction and carbon sequestration in exchange for credit toward meeting their required reduction targets.

${ }_{3}^{3}$ The JI mechanism allows for collaborative efforts between two or more industrialized countries in meeting their respective reduction targets.

${ }_{4}^{4}$ The ET mechanism establishes modalities for selling and buying emissions right. It regulates the carbon market.
} 
arises as to why reducing emissions from deforestation and degradation was excluded. Alvarado \& Wertz-Kanounnikoff (2008) argue that it is not unrelated to the techno-scientific, political and methodological complexities. We will examine these obstacles later in the chapter.

Nevertheless, at The Hague meeting in 2000, the issue of avoided deforestation was brought up during deliberations on the eligibility of land use, land-use change and forestry (LULUCF) activities under the CDM. This issue was raised when Annex I Parties reported emissions from deforestation in annual GHG inventories. The concern over emissions from deforestation prompted COP to reach two compromises at The Hague as outlined in the following excerpt from Karsenty (2008):

The compromise position proposed by President Pronk (Decision 1/CP.6) prior to the suspension of COP6 was to (1) designate avoided deforestation and combating land degradation and desertification in non-Annex I countries as adaptation activities eligible for funding through the Adaptation Fund but not through the sale of carbon credits; (2) allow only afforestation and reforestation projects in the CDM, with measures to address non-permanence, social and environmental effects, leakage, additionality and uncertainty (Karsenty, 2008).

This was evidently the first step toward the development of the REDD mechanism. This was followed by a series of behind-the-scenes meetings between some Annex I Parties and nonAnnex I Parties. Collaborations between the two Parties led to the submission of a proposal by governments of Papua New Guinea (PNG) and Costa Rica (with the support of the Coalition for Rainforest Nations), to COP11 in Montreal in 2005, calling for COP to consider possible approaches to address the issue of avoided deforestation. This initiative by PNG and Costa Rica prompted COP to urge Parties to engage in a two year study of the technical, scientific, methodological, and policy and positive incentives approaches related to the issue of avoided deforestation. Hence after two deliberative workshops in Rome and Cairns, COP at its $13^{\text {th }}$ meeting in 2007 in Bali, Indonesia, adopted a decision creating the REDD mechanism.

\section{The concept of REDD}

The concept of REDD comes from the broader ecosystems services concept developed by ecological economist Robert Costanza et al. (1987) in their pioneering work titled, The value of the world's ecosystem services and natural capital. Costanza et al. argue that ecosystems have economic value which must be factored into the market economy if we are to slow down or halt the global destruction of the world's natural environments. Services derived from the natural environment such as "regulating services (climate or water), provisioning services (food, fresh water), supporting services (soil conservation, nutrient cycling) and cultural services (aesthetic or traditional values)" (Alvarado \& Wertz-Kanounnikoff, 2008), can be accounted for, by evaluating the direct economic value of their provision. For example, how much will it cost the U.S. state of Florida to build a water purification system that can replace the natural purification functions of the Everglades wetlands system in the coast of Florida? Although some will argued that an estimate cannot be made given that the wetlands functions of the Everglades cannot be replaced by any man-made machine, the system of 'payments for environmental services' (PES) would at least in economic terms, allow for an estimate which can then be used as incentive to protect the wetlands of the Everglades. The same principle is applied with REDD whereby through direct financial 
incentives and financial flows from carbon markets, developing countries (mainly in the tropical forests regions) are encouraged to reduce carbon emissions by adopting strategies that would improve their capacity to reduce deforestation and forest degradation. Although financial flows from carbon markets have the potential to motivate emissions reduction from deforestation and forest degradation in developing countries, the greatest potential is in direct financial incentives from the global community. According to the UN-REDD strategy program, direct financial incentives of US\$22-38 billion between 2010 and 2015 would lead to an estimated 25 percent reduction in annual global deforestation rates by 2015 (United Nations- Reducing Emissions from Deforestation and forests Degradation [UNREDD], 2010). Although the financial incentives approach is more likely to be favored for a post-Kyoto implementation, "the majority of country proposals to the UNFCCC are in favor of a mixed [market mechanisms and financial incentives mechanisms] approach" (Parker et al., 2008).

\section{Deforestation and climate change}

The world's total forests area is estimated just over 4 billion hectares (Global Forest Resource Assessment [GFRA], 2010), covering more than one-quarter (31\%) of the world's total land area. However, the world's forests cover varies in distribution with less than $2 \%$ in the land area in some regions like North Africa, and up to $25 \%$ in others like Europe (GFRA, 2010). Global forests also vary in cover types including the boreal forests $(\sim 1.3$ billion hectares), the temperate forests $(\sim 1.0$ billion hectares), and the tropical forests $(\sim$ 1.7 billion hectares) (Gorte \& Sheikh, 2010). These forests play an important, but unequal role in global carbon budget as they are sinks - sequester carbon thus contribute to climate change mitigation - and sources of carbon - emits GHG, especially $\mathrm{CO}_{2}$ through deforestation. While the total carbon content of the global forests in 2005 was estimated at about $638 \mathrm{Gt}$, tropical forests store, on average, about $50 \%$ more carbon per unit area, than temperate and boreal forests. For example, with a total area of about 1.7 billion hectares, tropical forests store about 442 metric tons of $\mathrm{CO}_{2}$ per hectare of plant carbon compared to temperate and boreal forests which store only about 208 and 236 respectively (Gorte \& Sheikh, 2010). Although the current rate of tropical deforestation (2010) shows an overall decrease of about 3 million hectares in the last ten years (GFRA, 2010), it is still unacceptably high given the important role forests play as sinks and sources of carbon. More so, in terms of net loss, South America and Africa which are home to two of the world's three major tropical forests regions registered the highest net loss ${ }^{5}$ of forests between 2000 and 2010 - approximately 7.3 million hectares per year (GFRA, 2010). Given that tropical forests store on average, $50 \%$ more carbon per unit area than the two other major forests types (temperate and boreal), the global decrease of carbon stock in forests (at an estimated 0.5 Gt per year between 2005 and 2010) can be attributed to the net loss in tropical forests. The release of soil carbon into the earth's atmosphere is also linked to deforestation as deforestation leads to soil exposure and disturbance (tilling), increase dead matter, and increase soil temperature and rate of soil carbon oxidation (Gorte \& Sheikh, 2010). The boreal forests soils contain about $471 \mathrm{GtC}$ per hectares of land, which is more than twice the amount $(216 \mathrm{GtC})$ in tropical forests soils (Alvarado \& WertzKanounnikoff, 2008). Although tropical forests soils contain less than half the amount of

${ }^{5}$ Most of the loss was registered in the Amazonia forest in South America. 
carbon in boreal forests soils, the high level of activities (agriculture, mining, ranching, road development, etc) in tropical forests soils leads to more release of soil carbon into the earth's atmosphere.

\begin{tabular}{lllll}
\hline Forest Type & Area & Plant Carbon & Soil Carbon & Total Carbon \\
\hline Tropical & 1.76 & 442 & 450 & 892 \\
Temperate & 1.04 & 208 & 352 & 561 \\
Boreal & 1.37 & 236 & 1,260 & 1,496 \\
\hline
\end{tabular}

(Area in billion hectares; carbon in metric tons of $\mathrm{CO}_{2}$ per hectare)

Source: Adapted from Gorte \& Sheikh (2010)

Table 1. Average Carbon Stocks in the World's major Forests

In all, the IPCC estimates that deforestation contributes approximately $17 \%$ of global greenhouse gas emissions (IPCC, 2007), which is equivalent to about $5.8 \mathrm{Gt}$ of $\mathrm{CO}_{2}$ per year (UN-REDD, 2010). According to the IPCC, reduced deforestation and degradation is the forest mitigation option, as it has the largest and most immediate carbon stock impact with approximately $93 \%$ of the total mitigation potential in the tropics (IPCC, 2007). This also has direct positive implications for the natural environment, notably in the area of biodiversity conservation, as well as indirect positive implications for sustainable development, notably in the area of poverty reduction in developing countries in the tropics. Therefore, the mitigation of tropical deforestation and forests degradation is crucial in the fight against climate change. It is in this regard therefore, following the IPCC decision in 2007 establishing the REDD mechanism, that the conceptual framework for managing forests in developing countries has been in progress since 2008.

\section{REDD in the Congo Basin in Central Africa}

The Central Africa forests region expands across the borders of six countries - Cameron, Central African Republic, the Republic of Congo, the Democratic Republic of Congo, Equatorial Guinea, and Gabon - covering an area of approximately 330 million hectares that sits largely within the geologic confines of a Basin commonly known in geographic terms as the Congo Basin. It contains the second largest area of contiguous evergreen forest in the world. The expansive forests cover of the Congo Basin presents the region with the ability to make meaningful contribution in the fight against climate change via carbon sequestration and reducing emissions from deforestation and forests degradation (REDD), as it stores an estimated 25-30 billion tons of carbon in its vegetation (Hoare, 2007). The lowland forests of the region in particular, though represents only $35 \%$ of the land area, stores more than $60 \%$ of carbon (Nasi et al., 2009, as cited in Sonwa et al., 2011). Yet the region suffers from one of the highest deforestation and forest degradation rates in the world, making it one of the biggest sources of carbon emissions (Hoare, 2007; Streck et al., 2008). Between 1990 and 2000 the region suffered a net deforestation and net degradation of 0.19 and $0.10 \%$ respectively (Congo Basin Forest Partnership [CBFP], 2007); and an annual deforestation of $0.15 \%$ during the period 2000-2005 (Hansen et al., 2008, as cited in Sonwa et al., 2011). Although the region's deforestation during the period 2005-2010 was relatively low at $-0.23 \%$ per year (Food and Agricultural Organization [FAO], 2011), some studies (e.g. Zhang et al., 2002) show a projected increase of $1.3 \%$ by 2050 . This will mean significant emissions from deforestation and degradation because of the region's vast area of forests. 
It is difficult to separate deforestation from forest degradation as deforestation often paves the way for other activities that degrade the forest (Kaimowitz \& Angelsen, 1999). This point is raised in the region's initial REDD proposal to the UNFCCC in 2006, in which the region's potential contribution to emissions reduction from "deforestation and degradation" is emphasized (UNFCCC/FCCC/ SBSTA/2007/MISC.14, 2007). The proposal stressed the significance of including forests degradation to the reduction mechanism, arguing that "degradation constitutes the main cause of forest cover loss, likely to affect nearly $60 \%$ of productive lands in the Congo Basin" (Alvarado \& Wertz-Kanounnikoff, 2008). Also, because most of the countries in the Congo Basin already had or were in the process of developing forest degradation plans at the time the proposal was presented in 2006; they wanted to be rewarded for their early efforts (Karsenty, 2008). Even more important is that considering forests degradation as a mechanism for emissions reduction would increase overall emissions reduction than could be achieved with deforestation mechanism alone (Alvarado \& Wertz-Kanounnikoff, 2008). The UNFCCC reasoned with this proposal. Recognizing that it is difficult, if not impossible, to separate forests degradation from deforestation in a potential reduction of forest emissions mechanism, the UNFCCC shifted from its original position which was advocating "RED" - reducing emissions from deforestation - to a one that included forest degradation - reducing emissions from deforestation and degradation (REDD) - and officially endorsed the mechanism in Bali, Indonesia in 2007.

In line with its proposal to the UNFCCC, the Congo Basin countries have made progress in integrating forest degradation activities into the ongoing REDD pilot projects. This is shown by the current landscape of REDD activities distinguished by three groups of activities demonstration activities, readiness activities, and activities without explicit carbon goals (Wertz-Kanounnikoff \& Kongphan-apirak, 2009). Demonstration activities are those that are designed with carbon as the 'explicit objective'. Readiness activities are designed to prepare 'an enabling framework' for adopting and implementing any REDD mechanism that the UNFCCC might finally approve for a post-2012 Kyoto commitment. This includes preparing documents such as R-PINs (Readiness Plan Idea Notes) which involves capacity building through consultation with stakeholders, developing baseline projects to facilitate measuring, monitoring, and controlling emissions in order to avoid the problem of additionality, and RPPs (Readiness Preparation Proposals) which entails developing a national strategy framework. Activities without explicit carbon goals are those designed to promote the enhancement of ecosystems management activities such as payment for ecosystem services (PES) scheme, as well as sustainable development activities such as poverty reduction scheme. Most countries in the region are currently engaged in readiness activities with progress been made by Cameroon and the Democratic Republic of the Congo.

However, the region's ability to make meaningful contribution to emissions reduction could be tampered by a number of problems including - the inability to control emissions beyond project and country boundaries as reduced emissions in the region could be linked to increased emissions in industrialized nations (leakage), the issue of determining how much deforestation has been avoided and how much deforestation is too much deforestation (base-line), the limited ability of understanding how to deal with emissions on a long-term bases and avoiding short-lived benefits (permanence), the limited ability to respond to the demand for carbon credits as determined by the opportunity cost and the cost of implementing the REDD (price) and, dealing with issues of ownership of the land and illegal logging control caused by weak economic, political and legal structures, and poor 
industrial practices in the forestry and agricultural sectors (tenure and usage rights). These problems have become more evident in the past three years with the ongoing countryspecific pilot project experiences with the REDD mechanism and can be explained under two categories: (1) the techno-scientific and methodological category, and (2) the socioeconomic and political category.

The techno-scientific and methodological category is characterized by the following issues:

- Definitions - there are different definitions for forests and forest-related processes but currently there is no clear bottom-line definition applicable to the REDD mechanism. A crucial definitional issue is whether or not, and how to include plantations to the REDD mechanism since its already part of the climate change mitigation strategy under the clean development mechanism (CDM). But given that forest plantations have been linked to the loss of biodiversity (e.g. Butler, 2005), environmental NGOs like Greenpeace and WWF are opposed to the idea of including forest plantations in the definition. This is at odds with the already existing forests management plans in the Congo Basin which includes forest plantations, currently being pushed for acceptance by the UNFCCC. Although plantation forestry is very limited ${ }^{6}$ in this region, it has plenty of cash-crop plantations - palm, rubber, cocoa, coffee - that the region would benefit from (though at the disadvantage of the regions rich biodiversity) if forest plantations are included in the definition.

- Estimation and monitoring of stocks carbon cycle - As is the case with forests definitions, there is currently no scientifically accepted method for accounting for stocks and flows of carbon. However, a number of tools exist which have the potential to develop internationally recognized methodologies. The accrued knowledge of remote sensing and geographic information system are proving to be useful for this purpose. Although remote sensing is proving to be useful in this regard, its application in the Congo Basin remains largely at the regional and national scales, making it inefficient for place/site specific assessment which is crucial for any eventual future REDD mechanism in the region. The importance of this element of REDD in the Congo Basin is captured best in this statement by the Central Africa Forest Commission (COMIFAC) "No matter which final REDD mechanism is chosen, we will need to know as accurately as possible how much carbon is stored in different standing vegetation types (especially forests) and soils; released through AFOLU (agriculture, forestry and other land use) activities" (State of the Forest 2008, 2009, as cited in Central Africa Forests Commission [COMIFAC], 2010).

- Data availability - The estimation and monitoring of carbon stocks in the Congo Basin depends on quality data availability. The necessity for quality data has been emphasized by the IPCC data classification system ${ }^{7}$. This is very challenging for countries in the Congo Basin as they are required to use the best quality data "in order to make credible international claims for reduced degradation and forest carbon enhancement" (Skutsch et al., 2009). Although few pilot projects are currently going on

\footnotetext{
${ }^{6}$ As of 2010, only one large industrial forest plantation existed in the Congo Basin - Eucalyptus du Congo (ECO s.a.) - in Pointe Noire, Republic of Congo (Sonwa et al., 2011).

7 The IPCC monitoring standard places data in three tiers in ascending order of quality (Skutsch et al., 2009): Tier 1 - highly generalized data that may not represent actual condition on the ground. Tier 2 data derived from national-level activities that may be closer to on-the-ground conditions but may still not be accurate. Tier 3 - data derived from specific on-the-spot measurement with low error factor.
} 
(e.g. Australia, Brazil, Cameroon, Guyana, Indonesia, Mexico, Tanzania) in which data from site-specific measurements are inventoried for carbon estimation analysis, the cost associated with gathering quality data (Zahabu et al., 2005; Tewari \& Phartiyal, 2006; Karky, 2008) in a forest changing scenario, together with the lack of know-how by the local people is a drawback to the REDD mechanism in the region.

- Market-based instrument - A drawback to the REDD market-based instrument for the Congo Basin countries is the concept of a historical baseline. In spite of the plethora of empirical data documenting deforestation activities in the Congo Basin, most countries in the region still have relatively low deforestation rates (Dooley, 2009) compared to countries in other forest regions such as Asia (e.g. Indonesia) and the Amazon Basin (e.g. Brazil). It is a paradox that the comparably low deforestation rates in the Congo Basin works to the disadvantage of countries in the region, when it comes to the carbon markets baseline instrument under the REDD mechanism. This excerpt from Dooley (2009) explains the paradox of the historical baseline concept more clearly:

For forest credits to be traded in international carbon markets, the reductions in emissions must be measurable, and they must be over and above what would have happened otherwise. To measure this difference, a reference level must be established, which forms the baseline against which the impact of programs to reduce deforestation is measured. Most REDD proposals are based on the concept of a historical baseline: the reference scenario is determined on previous rates of deforestation, usually over a tenyear period, with the average forming the baseline. When emissions from deforestation (or any other activities included in a REDD agreement) fall below this rate, forest carbon credits are issued [...]. However, this approach favors countries with high rates of deforestation in the past. Countries with low deforestation rates, such as the Congo Basin countries - and those which have succeeded in reducing deforestation, such as Costa Rica and India - will not be able to claim emission reduction credits under this approach (Dooley, 2009).

The socio-economic and political category is characterized by issues relating to:

- Drivers of deforestation

- Sustainable forests management

- Regional and international cooperation

- Capacity building and

- Financial mechanisms.

The rest of this chapter will weave the aforementioned issues in an analyses of the socioeconomic, political and legal challenges of implementing the REDD mechanism in two countries in the Congo Basin - Cameroon and the Democratic Republic of Congo (DRC).

\subsection{Case analysis: Cameroon and Democratic Republic of Congo}

The country Cameroon is located at $6^{\circ} 0^{\prime} 0^{\prime \prime}$ North of the Equator and $12^{\circ} 0^{\prime} 0^{\prime \prime}$ East of the Greenwich Meridian. The southern part of the country constitute part of the Congo Basin forests with an estimated 17 million hectares of tropical forests, accounting for over onetenth of the remaining tropical forests in the Congo Basin (Sunderlin et al., 2000, as cited in Bellassen \& Gitz, 2008). The forests of Cameroon are home to more than 8,300 plant species, close to 300 mammal species, and 848 bird species (International Tropical Timber Organization [ITTO], 2006), and support the livelihoods of millions of Cameroonians. The Democratic Republic of Congo lies South-east of Cameroon at $4^{\circ} 31^{\prime} 0^{\prime \prime}$ South of the Equator 
and $15^{\circ} 32^{\prime} 0^{\prime \prime}$ East of the Greenwich Meridian. It is the second largest country in Africa with a total area of 2,345,410 $\mathrm{km}^{2}$ most of which (about 95\%) is forests. The DRC has an estimated forest area of about 133 million hectares (52\% of the Congo Basin forests), the largest confinement in Africa and the third largest in the world. Like in Cameroon, the forests of DRC are rich in species, and harbor some of the rarest and most endangered species of mammals in the world - gorillas, chimpanzees, elephants, etc. - birds, insects, and plants. However, in recent decades, the abundant forests in Cameroon and DRC have been disappearing at an alarming rate. In Cameroon, between 1980 and 1995 an estimated 2 million hectares of the forest was lost (Ichikawa, 2006). In 2000 the annual deforestation rate ranged between 80,000 and 200,000 square hectares (Ndoye \& Kaimowitz, 2000), a trend that continued throughout 2000s, leading to the loss of about 4.4 million hectares of forest between 1990 and 2010 (Cameroon Forest Information and Data, 2010). Degradation also poses a serious threat to the country's forests. With some of the richest species of timber ${ }^{8}$ in the world, the forests of Cameroon have attracted a lot of commercial logging enterprises over the years. Beginning in the 1970s, in an effort to bust its economy, the government of Cameroon encouraged large scale commercial logging in the country which opened up the forests for different environmental and socially damaging activities such as, road construction, slash-and-burn agriculture, hunting, illegal settlements, illegal logging, selective logging, plantation agriculture, and loss of cultural value (Mbatu, 2009). In DRC, logging practice that began in the 1920s gained momentum in the 1970s and 1980s. In spite of the devastating civil war in the 1990s logging activities continued, resulting to a 3\% loss of the country's forest between 1990 and 2005 (Congo Basin Program [CBP], 2011). Although official reports indicate that 500,000 cubic meters of timber is harvested annually from the forests of DRC, many observers, including the Food and Agricultural Organization (FAO), place the figure at more than double (CBP, 2011).

The alarming rate of deforestation and degradation made Cameroon and DRC attractive choices for REDD pilot projects. The first REDD pilot project in Cameroon was initiated in 2007 by Service Element on Forest Monitoring (GSE FM) of the Global Monitoring for Environmental and Security (GMES) ${ }^{9}$ with the aim of "integrating the application of Earth Observation (EO) technologies with the policy formulation" (COMIFAC, 2010). By integrating EO technologies with policy formulation Cameroon has made progress towards a national REDD framework as international cooperation ${ }^{10}$, collaborative work between the country's Ministry of Environment and Nature protection, GSE FM, and other stakeholders involvement has led to the development and approval of the R-PIN, and with the R-PP nearing completion. The REDD process was launched in DRC in January 2009. Through the collaborative efforts of many bilateral and multilateral partners led by the country's Ministry of the Environment, Nature Conservation, and Tourism (MECNT) the county is making steady progress towards a post-2012 national REDD framework strategy. The

\footnotetext{
8 Some of the most valued timber species in the forests of Cameroon include: Sapeli, Moabi, Azobé, Iroko, Okoumé Wengé, and Doussié.

${ }_{9}$ GMES is a joint venture of the European Space agency and the European Union that provides information on the global status of the environment mainly through the use of remote sensing and geographic information technologies.

10 Cameroon's REDD initiative has benefitted from a "south-south" cooperation with the Central American nation of Bolivia which is ahead of Cameroon in meeting the REDD modalities, especially with regards to the technical aspect of the REDD scheme.
} 
establishment of a national leadership team to coordinate the capacity building efforts led to the completion of the R-PIN with significant progress towards completing the R-PP. With significant financial and technical support from the international community both countries are on course to having a complete REDD national framework strategy in place by December 2012, just in time to begin implementing a post-Kyoto emissions reduction strategy. However, in spite of the overall progress, the emerging REDD framework for Cameroon and DRC faces a number of obstacles, especially in the area of sustainable forest management (SFM). Obstacles to SFM are generally tied to the driving forces of deforestation and forests degradation (figure 1) which many studies have attributed to a complex relationship between forest resources and socio-economic and political factors. In Cameroon and DRC the intricacies of policy and institutional factors - economic development, property rights, corruption, mismanagement, market and special dynamics, urbanization and industrialization, public attitudes, and values and beliefs (Mbatu, 2009) pose a threat to a successful adoption and implementation of SFM under REDD. The situation is even more complex in that forests provide the basic needs of a majority of people living in rural areas in these countries - fuelwood, timber, game, foodstuffs, raw materials, and other non-timber forest products. As Tieguhong (2008) notes, forest products represent up to $44 \%$ of the annual income of rural populations hence, constitute an important ecosystem for the economic wellbeing of the rural communities.

\subsubsection{Poverty}

Poverty is an important driver of deforestation (Angelsen \& Wunder, 2003; Fischer et al., 2005; Soriaga \& Walpole, 2007) and many studies in Cameroon (for example, Gbetnkom, 2008) and in DRC (for example, Iloweka, 2002) have documented the role poverty plays in forests loss and degradation in these countries. Reducing poverty in these countries, especially in forest communities could lead to lower rates of deforestation and degradation. However, Angelsen and Wunder (2003) have noted that increasing wealth of the rural poor does not generally translate to improved forest ecosystem since the accumulation of wealth, especially in the hands of a few elites could act as a springboard for attracting commercial logging enterprises.

\subsubsection{Agricultural expansion}

Agricultural expansion is another obstacle to the success of sustainable forest management under a potential REDD mechanism in these countries. Both subsistence and mechanized forms of agriculture play a significant role in forest loss and degradation in Cameroon and DRC. Deforestation happens in these countries partly due to agribusinesses undertaken by large multinational corporations involved in plantation agriculture. This is due largely to a growing demand for cash crops - notably robber, cocoa, palm nuts (Mitchell et al., 2007). Subsistence agriculture in forest communities in Cameroon and DRC like in most other countries in the tropics occurs through slash-and-burn, a practice that involves the cutting down of trees and burning them to open up an area for cultivation. After two or three seasons of cultivation the farmer abandons the plot and colonizes a new forest area as the old plot loses fertility due to the burning of the soil. This primitive practice, apart from its ecological downside, contributes significantly to both soil and forest carbon emissions. Bellassena \& Gutz (2008) in an assessment of differential revenues that "a farmer could get from 1 ha of land out of two alternative land-uses: shifting cultivation [slash-and-burn], the 
traditional land-use pattern in southern Cameroon, or carbon credits as compensation for the conservation of primary forest, ...found that a break-even price of $\$ 2.85 / \mathrm{t}$ of carbon dioxide equivalent would level shifting cultivation with "Compensated Reduction" (Bellassena \& Gitz, 2008)." The conclusion is that it is more profitable for the poor shifting cultivator farmer in Cameroon to preserve the forest under the REDD mechanism rather than to slash-and-burn it to grow crops. Unfortunately, in spite decades of educating this forest dwelling communities about the negative effects of practicing slash-and-burn agriculture, the practice still persists. This persistence can be linked to the poverty factor, a condition which the REDD mechanism must not undermined if it is to succeed in a post2012 emissions reduction mechanism.

\subsubsection{Increasing global resource consumption}

Another obstacle is the growing global demand for energy, materials, and industrial processes - notably mining and petroleum production. In Cameroon, a policy decision to exploit oil and natural gas in an ecologically sensitive coastal forest area in the Southwest Region in the early 1980s set precedence for deforestation and degradation of forests areas that harbor oil and mineral resources. Following this policy the government, in the late 1990s, made a decision to allow the landlocked nation of Chad to export its oil via the port of Kribi which led to significant forest loss. The project, which involved the laying of oil pipe lines from the oil field in Doba in Southern Chad to the port of Kribi in the South of Cameroon (over 1,070 km), is responsible for the loss of over $15 \mathrm{~km}^{2}$ of rainforest (Center for Environment and Development [CED], 2004). Another potential loss of forest under Cameroon's oil exploitation policy could come from the oil rich Bakassi peninsula which is home to rare species of plants and animals. Although oil resources have produced high rents and made substantial contribution to the national economy of Cameroon in the past 30 years $^{11}$, the continued falling output trends in the past 10 years has pushed the government to further open up forest areas for mining activities. For example, the discovery of a massive iron-ore deposit in the dense forest area near Mbalmayo in the East Region of the country has attracted the Australian mining company, Sundance Resources Ltd (Nyuylime, 2006). The company is forging ahead with mining operations in the area which has the potential of triggering extensive deforestation and degradation, mainly from infrastructure development such as roads and railways. Another mining prospect is the iron deposit located within the sensitive forest area at the western coast at Kribi. Though not currently under exploration, increasing demand for mineral resources from China has attracted Chinese companies in "obtaining exploration and exploitation rights to several bauxite reserves in the far northern portion of the country, at Minim-Martap and Ngouanda" (Reed \& Miranda, 2007), and may also attract these Chinese companies to the Kribi iron reserve which lies within the forest zone in the South Region. Although the revision of Cameroon's mining law in 2001 led to an overhaul of the mining code, it still enables dozens of small mining operations to take place within forests areas, which leads to deforestation and forests degradation. The DRC's mineral and oil exploration policies (World Bank, 2008) are similar to those of Cameroon. However, Reed and Miranda (2007) noted that "mining in DRC has been limited largely to the fringes of the [Congo] river and

11 Oil accounts for more than half of Cameroon's export earnings, around $24 \%$ of government revenue, and about $6 \%$ of GDP (Extractive Industries Transparency Initiative [EITI], 2006). 
forest systems that make access difficult" (Reed \& Miranda, 2007). This limited access could be attributed to the socio-economic and political instability the country went through during the last quarter of the last century. However, with growing political stability since the mid-2000s, and with the growing need of improving socio-economic conditions, it is likely that mining operations will occur in formerly less accessible forest areas. If provisions are not made in the REDD framework strategy for these countries to limit the extent and intensity of these activities within their forests areas; it could undermine the highly anticipated post-Kyoto emissions reduction contributions by these countries.

\subsubsection{Market failure}

A significant issue peculiar to most tropical timber exporting nations is market failure. Many services provided by tropical forests (table 2) are not traded in markets and, as a result have not established markets based on prices and therefore do not enter into the decisions of private and public sector actors (Pearce \& Warford, 1993). For example, in both Cameroon and DRC the government is the country's land owner who has the responsibility of maintaining lands under forest cover, but because the government does not get the full value of social benefits provided by forests, there is little or no incentive to protect the forests and the underlying lands. The market has failed to stimulate these governments and the private sector in the direction of socially based objectives. This causes these governments to misplace their priorities, hence, ushering in inefficiencies that lead to deforestation and forests degradation and, consequently, forest loss. Lack of information regarding the value of non-market benefits of forest is the reason for market failure (Pearce, 2001; WertzKanounnikoff, 2006). In Cameroon for example, Fomété (2001) notes that non-market goods such as biodiversity, watershed protection, recreation, and carbon sequestration appear to be of low importance to the government and to the local population hence, no incentives to actively engage in seeking information on the market value of forests and other environmental services. The failure of markets to capture the value of non-priced services of the forest is an indirect but meaningful cause of forest loss that shapes the non conservation attitude of forest exploiters in these countries. Therefore, assigning a price to the services provided by forests and charging the price to the beneficiaries of these services is a good strategy for the REDD mechanism for two reasons: (1) it reduces over exploitation of the forests (for timber, firewood, agriculture etc.) hence reducing emissions and (2) it generates income for the protector of these services. The concept of payment for environmental services is not new to the Congo Basin region. However, integrating it into the REDD mechanism would be challenging as a majority of the people in the region are very poor and depend on nature's free services for their livelihoods. Even with the significant funding by international organizations and financial institutions (for example, the United Nations Environment Program, the United Nations Development Program, the Food and Agricultural Organization, the African Development Bank and the World Bank) toward the implementation of the concept in the region, very little has been accomplished (Lescuyer et al., 2009). The land tenure crisis in the region will compound the problem for the REDD mechanism. This is already the case where a proposed project by Conservation International and the World Wildlife Fund to pay for biodiversity services in the Ngoyla-Mintom forest and the Bonobo forest in Cameroon and DRC respectively has been delayed due to land ownership contentions (Lescuyer et al., 2009). 


\begin{tabular}{|c|c|}
\hline Regulatory functions & Productive functions \\
\hline $\begin{array}{l}\text { The forest provides support to economic } \\
\text { activities and human well-being by: } \\
\text { - climate regulation } \\
\text { - hydric regulation } \\
\text { - protection against soil erosion } \\
\text { - maintaining biodiversity } \\
\text { - carbon sequestration } \\
\text { - recycling organic matter and human } \\
\text { Waste } \\
\text { Physical support functions } \\
\text { The forest provides the space and re- } \\
\text { quired substrates for: } \\
\text { - habitat } \\
\text { - farming zones } \\
\text { - recreational sites } \\
\text { - conserved natural spaces }\end{array}$ & $\begin{array}{l}\text { The forest provides basic resources, } \\
\text { notably: } \\
\text { - building materials: wood, lianas... } \\
\text { - energy: fuelwood... } \\
\text { - food resources: non-timber products, } \\
\text { game... } \\
\text { - medicinal resources } \\
\text { - genetic resources } \\
\text { Informational functions } \\
\text { The forest provides esthetic, cultural and } \\
\text { scientific benefits: } \\
\text { - source of cultural and artistic inspiration } \\
\text { - spiritual information } \\
\text { - historic, scientific and educational } \\
\text { information } \\
\text { - potential information }\end{array}$ \\
\hline
\end{tabular}

Source: Lescuyer et al., 2009

Table 2. Categories of Environmental Services Provided by Forests

Not only are services provided by the forests in the Congo Basin not traded in markets but charges paid by timber concessionaires in the region are relatively low compared to the market value of the resource (Fomété, 2001). These low charges are encouraging foreign timber companies especially from countries with rapidly growing economies like China to aggressively seek concessions here. In fact, the Chinese company Vicwood-Thanry which began exploring Cameroon's forest in 1997 now owns 12\% of foreign-owned concessions in Cameroon (Topa et al., 2009). There is also the lack of incentive for long term management due to logging competition among the many concessionaires. High profits due to low charges are also potential drivers of corruption that has handicapped strict enforcement of concession terms (Sieböck, 2002).

\subsubsection{Inefficient tax system}

Poor or mistaken tax policies have created obstacles to the sustainable management of forests in Cameroon [and DRC] (Sikod et al., 1996). In an effort to resolve the issue of market failure, the government of Cameroon under the 1994 forest policy embarked on reforming the forestry taxation system, output targets, regulation, private incentives and macroeconomic management, using policy instruments such as royalty ${ }^{12}$ for the forest area, felling tax, exit duty on logs, and factory taxes. ${ }^{13}$ These policy interventions have instead created controversies which have contributed to more deforestation in some areas. For example, the lack of concrete modalities for handling tax revenues and rents from royalties

\footnotetext{
12 Royalties are "rents" not "taxes," but are placed under tax regulations to ensure that concessionaires pay for the right to access the resource.

${ }_{13}$ Exit duty on sawn products and entry taxes on logs taken into factories.
} 
has made the policy vulnerable to fraud, evasion, and misappropriation. For instance, rents from the royalties are rarely distributed as stated in the loggers' condition of contract (Fomété, 2001). Logging companies have taken advantage of the weak modalities to benefit from the system by making only partial payments to the communities and direct contributions in kind to the villagers. In some cases, powerful elites have made deals with loggers that benefit only them and not the community. In such cases, the local populations do not get the social benefits (roads, schools, hospital etc) as stipulated in the conditions of contract. This depravity fosters illicit activities as forest dwellers become engaged in clandestine logging in an effort to meet their needs (Cerutti \& Tacconi, 2006). Another revenue related issue is the boundary problem. Neighboring forest villages often have quarrels related to boundary issues. This is because the larger the forest estate, the more benefit the local populations gets from it. Boundary problems are particularly challenging to authorities as lack of consensus between all stakeholders due to the absence or improper consultations with the local populations has led to vague provisions that lack legislative clarity. In DRC the situation is much the same. Klaver (2009) has noted that even though the 2002 forestry law clearly stipulates that local authorities are entitled to $15 \%$ of all forest related taxes and $25 \%$ for provincial governments "no funds have been transferred to provincial or local governments because they still lack the necessary legal authority and rights" (Klaver, 2009).

Another problem with the forest taxation system of these countries is lack of transparency. There is little or no flow of information between the different stakeholders. Most forest inhabitants in both countries are illiterate. The few who can barely read and write find it difficult to interpret policy documents. This is a huge limitation which, coupled with the lack of adequate information to estimate their expected revenue, causes inhabitants to fall prey to the greedy loggers and government official imposters. An even more serious problem with the forestry taxation system of these countries is that though it claims to be a decentralized system, both governments still place strong emphasis on centralized decisionmaking, ownership and control of forest resources. In Cameroon for example, the creation of community forests under the 1995 forestry law was aimed at giving complete autonomy for managing the forests to the communities themselves. However, communities are still unable to fully control the management process as local, national and regional government representatives sit in management committees and impose government directives on community leaders (Assembe, 2006; Mbatu, 2010). This has caused the local population not to cooperate with the government in managing the forests. These centralized decision-making policies have been partly responsible for failures to protect forests and for its extensive loss and degradation in Cameroon. The decentralization of forest management in Cameroon was meant to act as a model for the Central African region but in many ways has fallen short of the desired prototype. Though not a prototype of an ideal decentralized management system, the model has been adopted by some countries in the region including DRC which adopted a new forestry law in 2002 and passed a new constitution in 2006 (Government of DRC, 2006) in a move aimed at empowering communities to take control over the management of local forests. Although the 2006 constitution "stipulates that taxes are to be collected by decentralized autonomous local governments (Government of DRC, 2006), all forests-related taxes are [still] been paid directly to the national Treasury" (Klaver, 2009).

\subsubsection{Lack of secure land tenure}

The local populations in many communities in Cameroon and DRC have little or no incentive to protect the forest resource because they feel they have no stake in it as the 
governments of these countries continue to appropriate forest lands and its resources. About 97\% of natural forests in Cameroon belong to the government, while all natural forests in DRC are government owned (Cotula \& Mayers, 2009). This clearly shows that land tenure in both countries is unclear or insecure even though both countries allocate community forests for the benefit of the communities. In the absence of well-defined property rights (complete specification of rights, exclusive ownership, transferability, and enforceability) the forest has become a "common property" with the local populations engaging in forest clearance as a way of showing occupation and ownership. They base their actions on the customary law of droit de hache - axe right - whereby, ownership of land and its resources is acclaimed by putting it into productive use, by cutting down of trees. The use of common property leads to externalities ("tragedy of the common") as no one is liable for the cost of the externalities. Although the governments of Cameroon and DRC continue to exercise "authoritarian and repressive policing" in their forests sectors, the "limited government capacity to monitor compliance and sanction non-compliance" (Cotula \& Mayers, 2009) has allowed the customary law practice of droit de hache to continue. A challenge for the REDD mechanism in Cameroon and DRC, and in all other Congo Basin countries therefore, would be to help amend current decentralization policies and encourage genuine land tenure reforms that would lead to effective local control of forest management.

\subsubsection{Population pressure}

Like many other natural resources, deforestation and forest degradation in Cameroon and DRC has been linked to population pressure. According to World Bank, World Development Indicators 2000, Cameroon and DRC have the highest population density in the region with a combined population of 73.85 million inhabitants. Within the past five years both countries have witnessed rapid increases in populations, with the population of Cameroon increasing from 16.30 million in 2005 to 19.7 million in 2011 (Central Intelligence Agency [CIA], 2011) while that of DRC increased from 57.5 million in 2005 to 71.7 million in 2011 (CIA, 2011). This increase in population will increase the demand for land to cultivate and fuelwood for energy. It will also lead to cheap labor and generate high profits for agribusiness owners, making them more viable and having the desire for more land to expand their business. Increase in population will also lead to increase poverty as too many people will depend on few individuals for support. According to the United Nations Development Program's Human Development Index ${ }^{14}$ of 2006, Cameroon and DRC rate among the lowest in the region. The increase poverty will caused many families to depend totally on the forests for survival, through logging and slash-and-burn farming. The problem of population pressure is not only within these countries. The pressure is also coming from outside. Global population growth, together with economic growth mainly from industrialized countries has led to excessive foreign consumption of tropical produce like banana, cocoa, rubber, and palm nuts within the past two decades. Cameroon has responded to this increase in demand by adopting policies that support agricultural extensification hence, expanding its area of cultivation at the expense of the forests. For

\footnotetext{
14 The Human Development Index is a multidimensional concept of measuring human development that goes beyond income. It includes three key measurable dimensions - life expectancy at birth, adult literacy and gross enrolment in primary, secondary and tertiary levels, and per capita GDP (PPP US\$).
} 
example, since 1991, the Cameroon Development Corporation has expanded about 1,340 hectares of its plantations into the Onge-Mokoko forests in the Sourhwest province of Cameroon (Acworth et al., 2001).

\subsubsection{External debt servicing and misguided macro-economic policies}

Debt service and low per capita income is another obstacle to sustainable forest management in Cameroon and DRC. External pressure from the International Monetary Fund (IMF) and World Bank to recover debts owed them by the governments of these countries has left both nations' forests vulnerable. For example, the forest policy adopted by the government of Cameroon in 1994 was strongly influenced by the World Bank and the International Monetary Fund, mainly through the Structural Adjustment Program (SAP) that favors longer durations of concessions to logging companies, and encourages large forest areas for concessions (Ekoko, 1997). Most structural adjustment policies prescribed by the World Bank and the IMF are meant to liberalize the economies of countries adopting them and open up their markets to global economy. Instead, it has presented mixed fortunes for developing countries. Since its inception only a few countries like China, Brazil and Indonesia have been able to get meaningful benefits from the program. The rest of the developing countries have instead witnessed economic downturns (Brown \& Quiblier, 1994). In Cameroon, reduction in public spending has instead led to unemployment forcing people to rely on subsistence farming at the detriment of the forest (Benhin \& Barbier, 1999; Gbetnkom, 2008). In DRC the SAP created a situation where high unemployment (Jauch, 1999) left many families to rely on agricultural encroachment on forests lands for survival. The IMF call for economic liberalization in recent years has also not yielded much for the people as the economic indexes of both countries remains low. According to the 2011 Heritage Foundation and Wall Street Journal's Index of Economic Freedom report, Cameroon's per capita income is $\$ 2,147$. Its FDI inflow is $\$ 337.5$ million (Index of Economic Freedom, 2011). However, its external debt fell from an all-time-high of $\$ 11.11$ billion in 1998 to $\$ 2.94$ billion in 2009 (World Bank, 2009); thanks to the increased revenues from the forest sector (Fometé \& Cerutti, 2008). The situation in DRC is no better. The country's current (2011) external debt is $\$ 13.5$ Billion. Its per capita income of $\$ 332$ is one of the lowest in Africa. Its FDI inflow is equally low at $\$ 2.1$ billion (Index of Economic Freedom, 2011). High debts, low FDI and weak economies have left the peoples of Cameroon and DRC with little option but to continue deforesting and degrading their land for a livelihood.

In all, a combination of economic pressures to accelerate harvesting, corruption, the weakness of government forest administration, inappropriate concession license allocation and timber taxation systems, and the negative impacts of macroeconomic trade, population pressure, and Structural Adjustment Program polices have led to decades of unsustainable forest management in Cameroon and DRC.

The aforementioned obstacles to sustainable forest management in Cameroon and DRC are summarized in the following conceptual framework model (figure 1 - influence diagram) of direct and indirect causes of forest loss and/or degradation. Although the influence diagram appears to show some agents as directly linked to deforestation, there is actually no clear cut separation of direct and indirect causes of deforestation. In reality, forest loss is the result of long chains of causation that are not linear, but have feedback loops at some points or stages in the causation chains (Angelsen \& Culas, 1996). 


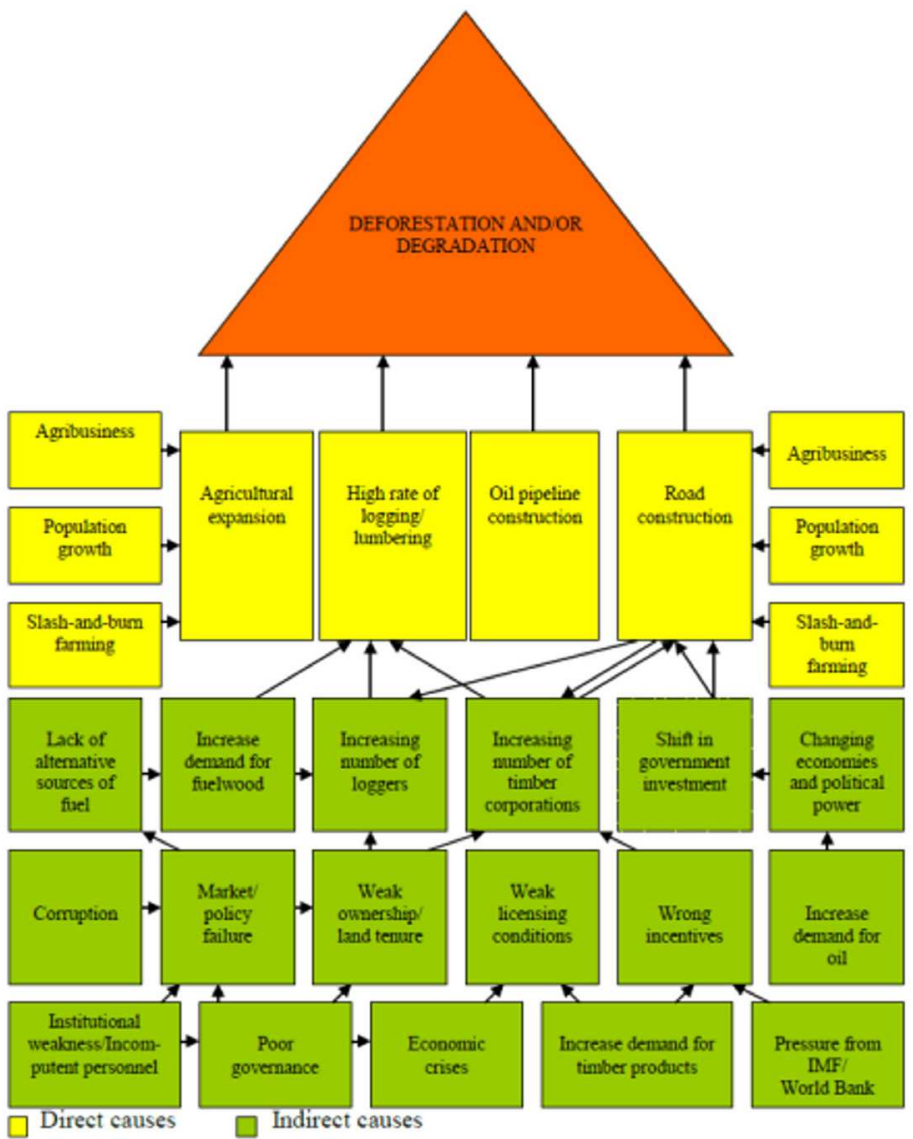

Fig. 1. Influence Diagram of Direct and Indirect Causes of Deforestation/Forest Degradation in Cameroon and the DRC

\section{Conclusion}

With the Kyoto protocol failing to meet its goal of reducing emissions of greenhouse gasses below the pre 1990 level by 2012, the IPCC now sees REDD as an indispensable element for the success of a post-2012 climate regime. After many decades of neglecting the importance of avoided deforestation and forest degradation in the fight against climate change, the IPCC in 2000 began integrating degradation schemes in its emissions reduction regime; thanks to the empirical evidence that deforestation and forest degradation accounts for about 17 percent of global greenhouse gas emissions, and that the world's forests sequester more carbon than it is in the atmosphere (Rogner et al., 2007; IPCC, 2007). The integration of REDD in the global emissions reduction regime does not only contribute in reducing carbon emissions and conserving biodiversity and sustaining ecosystem services, but also presents a tremendous opportunity to enhance living conditions for the world's poorest people, most of who live in forest communities in the tropics. The Congo Basin region of Central Africa in 
particular, has a lot to contribute and benefit from REDD. The vastness of the forests in this region means a significant amount of carbon could be sequestered here if REDD were to succeed in the region. The Democratic Republic of Congo alone, it is estimated, has a REDD potential of over 400 million tons of $\mathrm{CO}_{2}$ per year through 2030 (Kabila,15 2011). In spite the tremendous opportunity REDD presents to reduce carbon emissions and foster sustainable forest management in the Congo Basin region, the obstacles discussed in this paper (and can be extrapolated to all the countries in the region) must first be overcome. Although the region faces techno-scientific problems, the biggest obstacles to meeting the goal of REDD are of socio-economic and political nature. To overcome these obstacles, a number of measures must be taken by the national REDD Coordination and Management Teams (CMTs) of various countries in the region. First, is the need for capacity building of the various CMTs. At moment, the CMTs are made up of officials from two or more government ministries and representatives from a few national and international non-governmental organizations, whose lack of coordination is, itself, an obstacle to the national coordination effort the teams are charged with. A CMT whose activities are well coordinated is more prepared to deal with socio-economic and political issues that are a potential hindrance to the success of the national REDD strategy. Second, all stakeholders must be included at every level, and at all stages of development and implementation of the REDD strategy. This will help move the process in the direction of a pro-poor approach in which, traditional farmers, hunter-gatherers, community forest managers, indigenous peoples (especially the pygmies), traditional leader, municipal councils, regional councils, etc. contribute in making decisions that directly relate to their needs. Third, countries in the region must adopt a coherent policy to address the issue of tenure and other related rights of the indigenous forest peoples to access forests and its resources. This will give REDD's investors (public and private) and its global partners a sense of security when it comes to possible tension with local groups. This will also empower the local peoples as secure tenure provide them "more leverage in relations with government and the private Sector" (Cotula \& Myers, 2009). Fourth, to jointly address climate change and rural poverty under REDD would require sustainable forest management practices that confirm with the market tenets of ecosystem services. For this to be achievable, countries in the region will have to adopt measures that improve their economic and financial systems; specifically, measures that will enable them to uphold their "socio-environmental services and capital in [their] economic and political choices." Finally, REDD CMTs in the region must learn from the past successes and failures of other resources management initiatives in the agricultural and forest sectors, and the global carbon market. Specifically, attention must be given to issues related to capacity building and incentives (e.g. developing effective arrangements to channel benefits to the local level), legal framework and policy (e.g. connecting national laws and policy to relevant international principles and norms), education and information and culture (e.g. support for training workshops on resource knowledge, ecosystem management, biodiversity conservation, and cultural integration).

\section{Acknowledgement}

I will like to thank the anonymous reviewers for their comments on the initial draft of this chapter. Your comments have greatly shaped the outcome of this chapter.

\footnotetext{
${ }^{15}$ Kabila is the President of the Democratic Republic of Congo. He is referenced here citing a report by Mc Kinsey \& Co, a consulting company for the DRC REDD initiative.
} 


\section{References}

Acworth, J.; Ekwoge, H.; Mbani, J. \& Ntube, G. (2001). Towards Participatory Biodiversity Conservation in the Onge-Mokoko Forests of Cameroon. Rural Development Forestry Network Paper No.25d, (July), pp. 1-20

Alvarado, L. \& Wertz-Kanounnikoff, S. (2008). Why are we Seeing "REDD"? An Analysis of the International Debate on Reducing Emissions from Deforestation and Degradation in Developing Countries. IDDRI Analysis, No. 01/2008, Natural Resources, IDDRI, Paris, France

Angelsen, A. \& Culas, R. (1996). Debt and Deforestation: A Tenuous Link. Working Paper No.10, Chr. Michelsen Institute, ISSN 0804-3639

Angelsen, A. \& Wertz-Kanounnikoff, S. (2008). What are the key Design Issues for REDD and the Criteria for Assessing Options. In: Moving Ahead with REDD, A. Angelsen (Ed.), pp. 11-21, ISBN 978-979-1412-76-6, CIFOR, Bogor, Indonesia

Angelsen, A. \& Wunder, S. (2003). Exploring the Forest-Poverty Link: Key Concepts, Issues, and Research Implications. CIFOR Occasional Paper No.40. Bogor, Indonesia.

Assembe, S. (2006). Decentralized Forest Resources and Access of Minorities to Environmental Justice: An Analysis of the Case of the Baka in Southern Cameroon. International Journal of Environmental Studies, Vol.63, No.5, pp. 681-689, DOI $10.1080 / 00207230600963825$

Barbier, E. \& Burgess, J. (2001). The Economics of Tropical Deforestation. Journal of Economic Surveys, Vol.15, No.3, (July 2001), pp. 413-433, DOI: 10.1111/1467-6419.00144

Bellassena, V. \& Gitz, V. (2008). Reducing Emissions from Deforestation and Degradation in Cameroon: Assessing Costs and Benefits. Ecological Economics, Vol.68, No.1-2, (December 2008), pp. 336- 344, DOI 10.1016/j.ecolecon.2008.03.015

Benhin, J. \& Barbier, E. (1999). A Case Study Analysis of the Effects of Structural Adjustment on Agriculture and on Forest Cover in Cameroon. Center for International Forestry Research and the Central African Regional Program for the Environment

Brown, N. \& Quiblier, P. (1994). Ethics and Agenda 21: Morals and Implications of a Global Consensus. United Nations Publications, ISBN-92-1-100526-4, New York

Butler, A. (2005). World deforestation rates and forest cover statistics, 2000-2005. 24.08.2011, Available from http://news.mongabay.com/2005/1115-forests.html

Cameroon Forest Information and Data. (2010). 21.05.2011, Available from http://rainforests.mongabay.com/deforestation/2000/Cameroon.htm

CBFP. (2007). The Forests of the Congo Basin: The State of the Forest 2006. Congo Basin Forest Partnership, 29.08.2011, Retrieved from

http://carpe.umd.edu/resources/Documents/THE_FORESTS_OF_THE_CONGO _BASIN_State_of_the_Forest_2006.pdf

CBP. (2011). Democratic Republic of Congo. 25.08.2011, Available from http://www.illegallogging.info/approach.php?a_id=70

CED. (2004). Inauguration: Pipeline. CED Press Release, June 12, 2004.

Cerutti, P. \& Tacconi, L. (2006). Illegal Logging and Livelihoods. CIFOR Working Paper No.35, Bogor, Indonesia, Retrieved from http://cameroun-foret.com/fr/system/files/18_61_48.pdf

CIA. (2011). World Fackbook. 25.08.2011, Available from https://www.cia.gov/library/publications/the-world-factbook/geos/cg.html 
COMIFAC. (2010). Monitoring Forest Carbon Stocks and Fluxes in the Congo Basin. COMIFAC International Conference, 2-4 February 2010, Brazzaville, Republic of Congo, GOFC-GOLD Report No44, Available from http://www.observatoirecomifac.net/carbonCconfBrazza.php

Costanza, R.; d'Arge, R.; de Groot, R.; Faber, S.; Grasso, M.; Hannon, B.; Limburg, K.; Naeem, S.; O'Neill, R.; Paruelo, J.; Raskin, R.; Sutton, P. \& van der Belt, M. (1987). The Value of the World's Ecosystems and Natural Capital. Nature, Vol.387, (May 1987), pp. 253-260

Cotula, L. \& Mayers, J. (2009). Tenure in REDD: Start Point or Afterthought? International Institute for Environment and Development, United Kingdom, ISBN 978-1-84369736-7

Dooley, K. (2009). Why Congo Basin Countries Stand to Lose out from a Market Based REDD. FERN, Briefing Note No.06, 19.08.2011, Available from

http:/ / www.scribd.com/doc/23775446/Congo-Basin-Countries-Lose-Out

EITI. (2006). Democratic Republic of Congo. 12.08.2011, Available from http://www.eitransparency.org/section/countries

Ekoko, F. (1997). The political Economy of the 1994 Cameroon Forestry Law. Working Paper No.3, Center for International Forestry Research ,Yaoundé, Cameroon

FAO. (2011). The State of Forests in the Amazon Basin, Congo Basin and Southeast Asia. A Report Prepared for the Summit of the Three Rainforest Basins, Brazzaville, Republic of Congo, 31 May-3 June, 2011

Fisher, R.; Maginnis, S.; Jackson, W.; Barrow, E. \& Jeanrenaud, S. (2005). Poverty and Conservation: Landscapes, People and Power. IUCN. Gland, Switzerland, ISBN 2-83170880-x

Fometé, T. \& Cerutti, P. (2008). Verification in the Forest Sector in Cameroon. Verifor Country Case, Study No.11, 25.08.2011, Available from

http://www.verifor.org/RESOURCES/casestudies/cameroon_case_study_full.pdf

Fomété, T. (2001). The Forestry Taxation System and the Involvement of Local Communities in Forest Management in Cameroon. Rural Development Forestry Network, Network Paper, No.25b, pp. 17-28

Gbetnkom, D. (2008). Forest Depletion and Food Security of Poor Rural Populations in Africa: Evidence from Cameroon. Journal of African Economies, Vol.18, No.2, pp. 261-286

GFRA. (2010). Global Forest Resources Assessment 2010. FAO Forestry Paper No.163, 20.06.2011, Available from www.fao.org/forestry/fra/fra2010/en/

Gorte, R. \& Sheikh, P. (2010). Deforestation and Climate Change, Congressional Research Service, 20.06.2011, Available from www.crs.gov

Government of DRC. (2006). Constitution de la République Démocratique du Congo: Cabinet du Président de la République, 2006 - Law 18.02.2006

Hansen, M.; Stehman, S.; Potapov, P.; Loveland, T.; Townshend, J.; DeFries, R.; Pittman, K.; Arunarwati, B.; Stolle, F.; Steininger, M.; Carroll, M. \& DiMiceli, C. (2008). Humid Tropical Forest Clearing from 2000 to 2005 Quantified by Using Multitemporal and Multiresolution Remotely Sensed Data. Proc Natl Acad Sci, USA, Vol.105, No.27, pp. 9439-9444

Hoare, A. (2007). Clouds on the Horizon: The Congo Basin Forests and Climate Change. The Rainforest Foundation, ISBN: 978-1-906131-04-3, London 
Huberman, D. (2007). Making REDD Work for the Poor: The Socio-economic Implications of Mechanisms for Reducing Emissions from Deforestation and Degradation. IUCN

Ichikawa, M. (2006). Problems in the Conservation of Rainforests in Cameroon. African study monographs, Vol.33, No.1, pp. 3-20

Iloweka, E. (2002). The Deforestation of Rural Areas in the Lower Congo Province. Earth and Environmental Science, Vol.99, No.1-3, pp. 245-250, DOI 10.1007/s10661-004-4028-0

Index of Economic Freedom. (2011). 26.08.2011, Available from http://www.heritage.org/index/country/

IPCC. (2007). Fourth Assessment Report. 12.06.2011, Retrieved from http://www1.ipcc.ch/

ITTO. (2006). Status of Tropical Forest Management 2005. ITTO Technical Series No24, pp. 305, Yokohama

Jauch, H. 1999. Structural Adjustment Programs: Their Origin and International Experiences. Labor Resource and Research Institute (LaRRI), Namibia

Kabila, J. (2011). Inventing REDD+: Democratic Republic of Congo. 18.08.2011, Retrieved from www.unredd.net/index.php?option=com_docman\&task=doc_download\&gid $=408$ $4 \&$ Itemid $=53$

Kaimowitz, D. \& Angelsen, A. (1999). Rethinking the Causes of Deforestation: Lessons from Economic Models. World Bank Research Observer Vol.14, No.1, (February 1999), pp. 73-98, DOI 10.1093/wbro/14.1.73

Karky, B. (2008). The Economics of Reducing Emissions from Community Managed Forest in Nepal Himalaya. PhD Thesis, University of Twente, Enschede, Netherlands

Karsenty, A. (2008). The Architecture of Proposed REDD Schemes after Bali: Facing Critical Choices. International Forestry Review Vol.10, No.3, (September 2008), pp.443-457, ISSN 1465-5489

Klaver, D. (2009). Multi-stakeholder Design of Forest Governance and Accountability Arrangements in Equator Province, Democratic Republic of Congo. Capacity Development and Institutional Change Programme Wageningen International, The Netherlands

Lasco, R. (2010). Facilitating Mitigation Projects in the Land Use Sector: Lessons from the CDM and REDD. World Agroforestry Centre, Los Baños, Laguna, Retrieved from http://irri.org/climatedocs/presentation_Lists/Docs/4_Lasco.pdf

Lescuyer, G.; Karsenty, A. \& Eba'a Atyi, A. (2009). A New Tool for Sustainable Forest Management in Central Africa: Payments for Environmental Services, In: The Forests of the Congo Basin: State of the Forest 2008, C. de Wasseige, D. Devers, P. de Marcken, R. Eba'a Atyi, R. Nasi, P. Mayaux (Eds.), pp. 127-140, Luxembourg

Mbatu, R. (2009). Forest Policy Analysis Praxis: Modeling the Problem of Forest Loss in Cameroon. Forest Policy and Economics, Vol.11, No.1, (January 2009), pp. 26-33, DOI 10.1016/j.forpol.2008.08.001

Mbatu, R. (2010). Deforestation in the Buea-Limbe and Bertoua Regions in Southern Cameroon (1984-2000): modernization, world-systems, and neo-Malthusian outlook. GeoJournal,Vol.75, No.5, pp. 443-458, DOI: 10.1007/s10708-009-9312-7

Mitchell, A.; Secoy, K. \& Mardas, N. (2007). Forests First in the Fight against Climate Change: The VivoCarbon Initative. Global Canopy Programme. Oxford, UK

Nasi, R.; Mayaux, P.; Devers, D.; Bayol, N.; Eba'a Atyi, R.; Mugnier, A.; Cassagne, B.; Billand, A. \& Sonwa, D. (2009). Un Aperc, $u$ des Stocks de Carbone et Leurs Variations dans les Fore^ts du Bassin du Congo. In: Les Fore ts du Bassin du Congo. Etat des Forêts 2008, C. Wasseige, D. Devers, P. de Marcen, R. Eba'a Atyi, R. Nasi, \& Ph. Mayaux (Eds.), pp. 199-216, ISBN 978-92-79-132 11-7, Office des publications de l’Union Europe'enne 
Ndoye, O. \& Kaimowitz, D. (2000). Macro-economics, Markets and the Humid Forests of Cameroon, 1967-1997. The Journal of Modern African Studies, Vol.38, No.2, (July 2000), pp. 225-253

Nyuylime, L. (2006). Mbalam Iron Ore Exploration Afoot. Cameroon Tribune, 27.10. 2006

Parker, C.; Mitchell, A.; Trivedi, M. \& Mardas, N. (2008). The Little REDD Book: A Guide to Governmental and Non-governmental Proposals for Reducing Emissions From Deforestation and Degradation. Global Canopy Programme, Oxford, 25.06.2011, Retrieved from www.globalcanopy.org/main.php? $\mathrm{m}=4 \& \mathrm{sm}=15 \& \mathrm{ssm}=151$

Pearce, D. \& Warford, J. (1993). World without End: Economics, Environment and Sustainable Development. Oxford University Press, New York

Pearce, D. (2001). The Economic Value of Forest Ecosystems. Ecosystem Health, Vol.7, No.4 (December 2001), pp. 284-296, DOI: 10.1046/j.1526-0992.2001.01037.x

Randolp, J. \& Masters, G. (2008). Energy for Sustainability: Technology, Planning, Policy. Island Press, ISBN 13:978-1-59726-103-6, Washington D.C.

Reed, E. \& Miranda, M. (2007). Assessment of the Mining Sector and Infrastructure Development in the Congo Basin region. WWF, Washington, D.C.

Rogner, H.; Zhou, D.; Bradley, R.; Crabbé, P.; Edenhofer, O.; Hare, B.; Kuijpers, L. \& Yamaguchi, M. (2007). Introduction, In: Climate Change 2007: Mitigation, B. Metz, O. Davidson, P. Bosch, R. Dave, \& L. Meyer, (Eds.), Contribution of Working Group III to the Fourth Assessment Report of the Intergovernmental Panel on Climate Change, University Press, Cambridge

Sieböck, G. (2002) A Political, Legal and Economic Framework for Sustainable Forest Management in Cameroon: Concerted Initiatives to Save the Rainforests. Masters Thesis, Lund University, Sweden, 18.08./2011, Available from

http://www.lumes.lu.se/database/alumni/01.02/theses/sieboeck_gregor.pdf

Sikod, F.; Amin, A. \& Nyamnjo, F. (1996). Interlinkages between Trade and the Environment: A Case Study of Cameroon. UNTAD/UNDP Project Report.

Skutsch, M.; van Laake, P.; Zahabu, E.; Karky, B. \& Phartiyal., P. (2009). Community Monitoring in REED+, In: Community Forest Management Under REED: Policy Conditions for Equitable Governance, A. Angelsen, M. Brockhaus, M. Kanninen, E. Sills, W.D. Sunderlin \& S. Wertz-Kanounnikoff) (Eds), pp. 101-112. Centre for International Forestry Research, Bogor, Indonesia

Sonwa, D.; Walker, S.; Nasi, R. \& Kanninen, M. (2011). Potential Synergies of the main Current Forestry Efforts and Climate Change Mitigation in Central Africa. Sustainability Science, Vol.6, No.1, pp. 59-67, DOI 10.1007/s11625-010-0119-8

Soriaga, R. \& Walpole, P. (2007). Forests for Poverty Reduction: Opportunities in the AsiaPacific Region, In: Forests and the Millennium Development Goals, Mayers (Ed.), pp.4748, European Tropical Forest Research Network. Wageningen, The Netherlands.

State of the forest 2008. (2009). Les Fore^ts du Bassin du Congo. Etat des Fore^ts 2008, C. Wasseige, D. Devers, P. de Marcen, R. Eba'a Atyi, R. Nasi, \& Ph. Mayaux (eds.), ISBN 978-92-79-132 11-7, Office des publications de l'Union Europe'enne, Retrieved from http://www.observatoire-comifac.net/edf2008.php

Streck, C.; O'Sullivan, R.; Janson-Smith, T.; \& Tarasofsky, R. (2008). Climate Change and Forests, Emerging Policy and Market Opportunities. Chatham House, Brookings Institution Press (2008), 346 pp. ISBN 978-0-8157-8192-9, London 
Sunderlin, W.; Ndoye, O.; Bikié, H.; Laporte, N.; Mertens, B. Pokam, J. (2000). Economic Crisis, Small-scale Agriculture, and Forest Cover Change in Southern Cameroon. Environmental Conservation, Vol.27, No.3, (July 2000), pp. 284-290

Tchiofo (2008)

Tewari, A. \& Phartiyal, P. (2006). The Carbon Market as an Emerging Livelihood Opportunity for Communities of the Himalayas. ICIMOD Mountain Development, No.49, pp. 26-27, Central Himalayan Environmental Association, Nainital, India

Tieguhong, J. (2008). Ecotourism for Sustainable Development Economic Valuation of Recreational Potentials of Protected Areas in the Congo Basin. PhD thesis, University of KwazuluNatal, South Africa

Topa, G.; Karsenty, A.; Megevand, C. \& Debroux, L. (2009). The Rainforest of Cameroon: Experience and Evidence from a Decade of Reform. Washington, DC: World Bank

UNDP. (2006). Human Development Index 2006: Beyond scarcity: Power, poverty and the global water crisis. Retrieved from http://hdr.undp.org/en/media/HDR06-complete.pdf

Unfc / fc / sbsta / 2007/misc.14. (2007). Views On Issues Related To Further Steps Under the Convention Related to Reducing Emissions from Deforestation in Developing Countries: Approaches to Stimulate Action: Submissions from Parties, 03.07.2011, Available from http://unfccc.int/resource/docs/2007/sbsta/eng/misc14

UN-REDD. (2010). The United Nations Collaborative Program on Reducing Emissions from Deforestation and Forest Degradation in Developing Countries: Program strategy 2011-2015. Retrieved from www.un-redd.org

Wertz-Kanounnikoff, S. \& Kongphan-apirak, M. (2009). Emerging REDD+: A Preliminary Survey of Demonstration and Readiness Activities. CIFOR Working Paper No.46, Bogor, Indonesia

Wertz-Kanounnikoff, S. (2006). Payment for Environmental Services: A Solution for Biodiversity Conservation? IDDRI Working Paper No.7, Natural resources, IDDRI, Paris, France

World Bank. (2005). World's World Development Indicators. 23.08.2011, Available from http:/ / devdata.worldbank.org

World Bank. (2006). World Bank's World Development Indicators database. 16.08.2011, Available from http://devdata.worldbank.org

World Bank. (2008). Democratic Republic of Congo: Growth with Governance in the Mining Sector. Oil/Gas, Mining and Chemicals Department AFCC2, Africa Region, Report No.43402-ZR.

World Bank. (2009). World Bank's World Development Indicators database. 25.08.2011, Available from http://devdata.worldbank.org

World Bank. (2011). World Bank's World Development Indicators database. 25.08.2011, Available from http://devdata.worldbank.org

Zahabu, E.; Malimbwi, R. \& Ngaga, Y. (2005). Payments for Environmental Services as Incentive Opportunities for Catchment Forest Reserves Management in Tanzania. Paper to the Tanzania Association of Foresters Meeting. Dar es Salaam, Tanzania, 6-9 November 2005

Zhang, Q.; Justice, C. \& Desanker, P. (2002). Impacts of Simulated Shifting Cultivation on Deforestation and Carbon Stocks of the Forests of Central Africa. Agric Ecosyst Environ, Vol.90, No.2, (July 2002), pp. 203-209, DOI 10.1016/S0167-8809(01)00332-2 


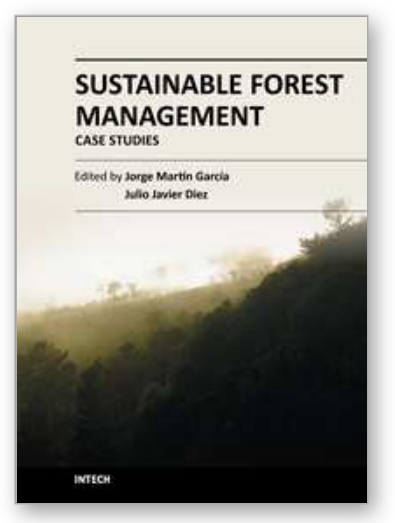

\author{
Sustainable Forest Management - Case Studies \\ Edited by Dr. Julio J. Diez
}

ISBN 978-953-51-0511-4

Hard cover, 258 pages

Publisher InTech

Published online 11, April, 2012

Published in print edition April, 2012

The concept of forest sustainability dates from centuries ago, although the understanding of sustainable forest management (SFM) as an instrument that harmonizes ecological and socio-economic concerns is relatively new. The change in perspective occurred at the beginning of the 1990s in response to an increased awareness of the deterioration of the environment, in particular of the alarming loss of forest resources. The book collects original case studies from 12 different countries in four continents (Africa, America, Asia and Europe). These studies represent a wide variation of experiences from developing and developed countries, and should clarify the current status of SFM worldwide and the problems associated with its implementation.

\title{
How to reference
}

In order to correctly reference this scholarly work, feel free to copy and paste the following:

Richard S. Mbatu (2012). Obstacles to a Conceptual Framework for Sustainable Forest Management Under REDD in Central Africa: A Two-Country Analysis, Sustainable Forest Management - Case Studies, Dr. Julio J. Diez (Ed.), ISBN: 978-953-51-0511-4, InTech, Available from: http://www.intechopen.com/books/sustainableforest-management-case-studies/obstacles-to-a-conceptual-framework-for-sustainable-forest-managementunder-redd-in-central-africa-a

\section{INTECH}

open science | open minds

\section{InTech Europe}

University Campus STeP Ri

Slavka Krautzeka 83/A

51000 Rijeka, Croatia

Phone: +385 (51) 770447

Fax: +385 (51) 686166

www.intechopen.com

\section{InTech China}

Unit 405, Office Block, Hotel Equatorial Shanghai

No.65, Yan An Road (West), Shanghai, 200040, China

中国上海市延安西路65号上海国际贵都大饭店办公楼405单元

Phone: +86-21-62489820

Fax: $+86-21-62489821$ 
(C) 2012 The Author(s). Licensee IntechOpen. This is an open access article distributed under the terms of the Creative Commons Attribution 3.0 License, which permits unrestricted use, distribution, and reproduction in any medium, provided the original work is properly cited. 